\title{
English Language Teaching Practice (ELTP) at Primary and Secondary School Levels in some Asian Countries: A Comparison of Afghanistan, Malaysia and Saudi Arabia

\author{
Mohammad Sharif Hassanzoy, Saifurrahman Rahmani, Sandaran SC.
}

\begin{abstract}
English language teaching is a significant part of schools' curriculum in native and non-native English speaking countries in the world. This study aims to present a review on the similarities and differences of ELTP (English Language Teaching Practice) at primary school level in three Asian countries: Afghanistan, Malaysia and Saudi Arabia. The paper discusses some of the similarities and differences of ELT practice at primary school level in these three Asian countries, based on teaching English as a foreign or second language ESL/EFL, when English as a subject is introduced in school, Policy towards English, religious and cultural perceptions towards English, methods of instruction, teaching aids and teaching materials, and challenges in ELT. The discussion shows that there are quite a few similarities between Afghanistan and Saudi Arabia regarding ELT practice at primary school level while in the case of Malaysia, ELT is more progressive and up to date in terms of policy and implementation. The paper also highlights some of the challenges faced by teachers in the three countries.

Keywords: English Language Teaching Practice (ELTP), EFL, ESL, Primary School Level
\end{abstract}

\section{INTRODUCTION}

ELTP (English Language Teaching Practice) engages numerous language educators in native and non-native speaking countries to announce how they teach English as EFL/ESL for learners. Although English language is practiced in three different circles such as inner circle (using English as first language), outer circle (using English as a second language) and expanding circle (using English as a foreign language), there are some similarities and differences regarding ELTP at primary, secondary and tertiary levels in native and non-native speaking countries [1]. While there are many studies on ELTP in Asian countries, but they do not look at how the practices are similar or different. Thus, this study aims to discuss of the similarities and differences of

Revised Manuscript Received on December 12, 2019.

Mohammad Sharif Hasanzoy* Faculty of Education, Department of English, Kunduz University, 3503, Kuduz, Afghanistan. Email: mohammadhasanzoy@gmail.com

Saifurrahman Rahmani, Faculty of Languages and Literature, Department of English, Sheikh Zayed University, Khost, 2501, Khost, Afghanistan.Email: saif.paktiawal2@gmail.com

Sandaran, SC. Language Academy, Faculty of Social Sciences and Humanities, Universiti Teknologi Malaysia, 81310, Johor Bahru, Johor, Malaysia.Email: shanti@utm.my

(c) The Authors. Published by Blue Eyes Intelligence Engineering and Sciences Publication (BEIESP). This is an open access article under the CC BY-NC-ND license (http://creativecommons.org/licenses/by-nc-nd/4.0/)
* Correspondence Author

English language teaching practice (ELTP) at primary school level in the context of three countries, namely, Afghanistan, Malaysia and Saudi Arabia.

English language teaching was initially introduced to the education system of Afghanistan in the late 1930 when it was only taught at secondary and tertiary level; however, after 2001 the language was introduced to the primary school curriculum [2]. Nevertheless, Malaysia has been experiencing English language teaching practice since 1957 and the language was formally issued on behalf of National Education Policy in 1970 [3], [4]. In the case of Saudi Arabia, the literature [5], [6] shows that English language has not been practiced at primary school level until 2004, while in 2011 it was introduced as a compulsory subject for years 1 to 6. It is worth mentioning that the status of the English language is that of a Second Language (ESL) in Malaysia and Saudi Arabia, and is taught as a foreign language (TEFL) in Afghanistan. The purpose of this paper is to discuss some of the similarities and differences of ELTP at primary school level in Afghanistan, Malaysia and Saudi Arabia based on aspects such as the status of English Language (i.e. ESL, EFL), policy, religious and cultural perspectives, teaching and learning methods and materials as some of the major challenges faced by teachers in ELTP in the selected Asian countries. The paper extends upon research on ELT practices to provide EL practitioners with a better understanding of some of the issues and concerns of teachers and students of English Language in these Asian countries.

\section{BACKGROUND AND HISTORY OF ENGLISH LANGUAGE TEACHING}

[7] explained that English language is highly appreciated and used as an interactive tool among nonnative speakers in the countries which belong to the expanding circle of Kachru's model., English Language has been introduced to Asian countries through two factors namely the immigration of many people from south and eastern England to America and Australia and colonization of Asia and Africa by the British Empire [7]. In Afghanistan, Malaysia and Saudi Arabia the English Language status is that as EFL or ESL for more than half a century [2], [6], [4].

[8] explicated that several Asian countries accepted English as a subject into their school curriculum because they believe the language is an effective contributor to the pupils' personal, linguistic, social and cultural improvement.

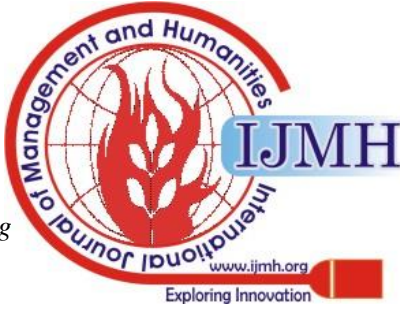


Based on Kachru's circle, Afghanistan comes into the expanding circle where English is taught and utilized as a foreign language (EFL) in various settings namely primary schools, secondary schools and universities [9]. [4] indicated that in Malaysian primary school English language is taught as a second language in all government supported schools. [10] argue that globalization and modernization are the two main reasons for the Kingdom of Saudi Arabia KSA to introduce the teaching and learning of English into its education system as a Second Language. Therefore, Malaysia and Saudi Arabia come in the outer circle of Kachru 's division

[12] states that as the ministry of education (MoE) in Afghanistan felt the importance of English language teaching in terms of understanding science and technology, they gave more priority to the teaching of English at primary and secondary levels. Nowadays English language is taught as a core subject in primary, secondary and tertiary levels in Afghanistan. In the case of Malaysia, [13] explained that the New Education Policy (NEP) introduced in 1970 that was based on the existence of a pluralistic society and the economic competition of Malaysia, had led to the nationalization of the English language [4, p. 483] indicated that "English is important in the country's quest for economic development as the global nature of the world has now made it the language medium for business, technology and knowledge". Similarly, Saudi Arabia, its educational policy declares that Arab students must understand and be educated at least one overseas language to which help them to communicate people from other cultures for the aim of deliver the message of Islam and provide humanitarian aids [14].

\section{ENGLISH AS EFL/ ESL}

Based on Kachru's (1982) circle, English language is viewed from three different angles such as inner circle, outer circle and expanding circle throughout the world. Since this study focuses on some Asian countries exclusively, English language is fitted into outer and expanding circles at primary schools in aforementioned countries. Furthermore, the country Afghanistan comes into the expanding circle where English is taught and utilized as a foreign language (EFL) in various settings namely primary schools, secondary schools and universities [9]. Conversely, [4] study stated that it is revealed from the curriculum of English language at primary school level that English is taught as second language in all public schools of Malaysia. Similarly, [15, p. 106] revealed that "Malaysia has accorded English as a second language status as stated in Article 152 and given due attention". Besides, observing English as a foreign language in Afghanistan, one of the major objectives of ministry of education is to provide students to be able to read some English books with their original text [16].

Similarly, English language in Saudi Arabia also has a historical importance. [17] stated that looking at history of English that was introduced for the first time in Saudi Arabia in the late 1920s, it was the time that language had little importance and faced with series resistance by society. Moreover, [18] adds that the time in which Saudi Arabia was one of the poorest countries, the development of English language teaching (ELT) was not so fast. English became part of the Saudi formal educational system to quicken the country's incorporation with other world. English is taught as a foreign language in Saudi Arabia schools and other educational institutions [19]. [11] explain that Saudi government passed a considerable amount of fundamental legislation in terms of EFL teaching. To meet the requirements of the twentieth century, to keep up-to-date with the education system and be connected to western education, Saudi Arabia found the Scholarship Preparation School (SPS) in 1936 in Makkah where English language teaching was introduced for the first time [11].

\section{START OF ENGLISH LANGUAGE AS A SUBJECT AT SCHOOL}

English language was introduced at primary school level either as a foreign or second language at different stages of primary school education in these Asian countries. Although, from 1996 to 2001 during the Taliban regime, English language was not part of the education system in Afghanistan, later it was included in the school curriculum to be taught for six years from year 7 to year 12 [20]. He argues that English became one of the compulsory subjects at primary schools where kids must start it in year 4 and continue until year 12. Conversely, in the case of madrasah (religious school) in Afghanistan English is to taught in year 8 , and in most madrasahs, the language is not taught at all [16].

This indicates that Afghan pupils are involved in studying English language for nine years in government supported schools. Similarly, in Saudi Arabia EFL was taught in different grades of public elementary schools. [11] explains that in 1943, Saudi government decided to introduce teaching of English beginning from year 7 until year 9 of the intermediate stage. Moreover, [18] adds that in the public schools, English was taught in year 7 in 2003. Then it was taught in year 5 and 6 and, last of all it was taught from year 4 at primary schools in 2012. [21] states that in the private schools, English has been taught as a subject from year 1 since 1970s.

On the other hand, in the case of Malaysia, [15] explicated that English was introduced as a second language to children from the very early age even when kids are in kindergarten.

They also explain further that Malaysian pupils aged four or five years are introduced to the English Language in the classroom [15, p. 106] stated that "They would then continue to learn English until they reach Form Five (17 years old)".

\section{POLICY PERSPECTIVES}

English as an international language depends on the needs of the nations. For the Asian countries, this is dependent on their needs in terms of communication, education and utilization of the language. In Afghanistan, the ministry of education felt a huge need for designing an appropriate language planning and educational policy-making to advocate English as a Foreign Language and facilitate equal chances for all primary school learners to acquire the language [9].

She added that applying the policies demanding English as the medium of instruction equipped with adequate conditions and sufficient training, tools and English materials.

Published By:

Blue Eyes Intelligence Engineering \& Sciences Publication tand $\mathrm{Hu}$ 
In Malaysia [21] explained that policy makers perceived English as a second language in their educational policies. In other words, the language is perceived officially in law, education, governmental offices, business and media in all over Malaysia. In addition, [22] stated that the new curriculum designed for primary schools highlights active learning, social and cultural values through language learning as well as it focuses on realizing the role of English not only inside the school but also in the outside world.

For Saudi Arabia, [23] stated that in order to have successful EFL program in early grades of the elementary level in Saudi Arabia, it should be taken into account carefully that the following policies are given attention: curriculum policy, personal policy, material policy, society policy and evaluation policy. Furthermore, [24] stated that it is suitable to claim that in Saudi Arabia, English language is perceived by policy-makers, stakeholders, and other decision-making bodies as an important tool for the development of the country in terms of both international relations and scientific- technological advancement. He added that in Saudi Arabia, English as the primary foreign language has the official status and the country now advocates more interest in English language program.

\section{RELIGIOUS AND CULTURAL PERCEPTIONS TOWARDS ENGLISH}

As language, culture and religion have a strong and remarkable relationship between each other, consequently people have different believes regarding English language particularly in Islamic countries. To support this, [25] argue that good EFL textbooks present learners scale of learning, including not only language but also culture. They also claim that instruction can be mostly persuasive with youngsters who internalize the concepts delivered to them in their textbooks as outright fact. In the Afghanistan context, [26, p. 3] believes that "They love their religion and traditions more than anything". Faiq also asserts that Afghan people need an English language curriculum founded on the philosophy of social reconstruction, religion observance and worldwide communication. Moreover, in Afghanistan mainly in rural areas, people believe that educating pupils via English language particularly children at primary school level means educating them with western culture [9].

Similarly, someone can find the same perception about educating English to school learners in Malaysia. [27] explicated that it was feared that schools which were built by the British in urban centers during their rule over Malaysia would entice Malaysians, specifically the majority Muslim Malays and their kids to convert to Christianity through the teaching of English language. [27] state that a large number of Malays dislike English schools because Islamic subjects were substituted with English ones. In addition, the new English language curriculum for Malaysian schools also focuses on social and cultural values and requires pupils to relate to the principles in and out of their schools [28], [29].

In Saudi Arabia English language plays a significant role in relation to the religion of Islam. [17] stated that from the religious perspective, English is a significant source through which communication takes place with 11 million pilgrims visiting every year to Mecca and Medina which are the holy places for Muslims. Moreover, English is considered a religious obligatory which plays a significant role in teaching Islamic values to non-Arabic speakers. Thus English can be used for the spreading of Islam [30]. Besides, Saudi Arabian people use English to communicate with people of different cultures and are able to disseminate the principles of Islam and translate for English speakers, Islamic knowledge. Thus English Language is seen as a medium for sharing knowledge about Islam which can help to eliminate the misconceptions about Islam in the West.

\section{METHODS OF INSTRUCTION}

Two writers of this article are from Afghanistan and they are English language lecturers so that they have good enough experiences about EFL. Here, the writers are keenly interested to share their own teaching experiences about method used for teaching EFL. Although, new methods and approaches have emerged and used in different Asian countries to teach English in primary schools, Afghanistan teachers still use the audio-lingual and grammar translation methods, mainly in primary and secondary schools. For instance, rote memorization and word for word translation are the two most dominant activities that primary school teachers follow to teach English for their pupils. [31] indicated that "While CLT has been in existence since 1970s, in Afghanistan as [32, p. 1] asserts Grammar-Translation Method and Audio-lingual Method have been dominant for many years and have negatively affected the communicative abilities of students".

Furthermore, in the case of Malaysia, [13] stated that three types of instructional methods were implemented in the very beginning, namely the grammar translation method, direct method and situational approach.

Additionally, currently there is no single method to be used at primary schools to educate English language. Although, CLT (Communicative Language Teaching) is the latest method of teaching English in the country, [33, p. 200] suggested that "The approach to teaching English in Malaysian schools is eclectic in which teachers may employ any method that gives due importance to both language learning and acquisition". In other words, Malaysian primary school teachers use any method that best provides pupils with communicative proficiency.

Likewise, English teaching method in Afghanistan, Saudi Arabia uses the grammar translation in schools to teaching English. [34] stated that the teaching method of Saudi Arabia is based on the traditional grammar translation method teaching that follow learning grammatical rules then applying them by translating sentences from L2 to L1. [35] finding maintain that existing traditional methods used to teach English in Saudi Arabia mostly follow audio-lingual and grammar-translation methods. In addition, selecting the traditional grammar translation method of teaching, the public schools of Saudi Arabia cannot employ contemporary techniques such as pair work, group work, role playing and interviews.

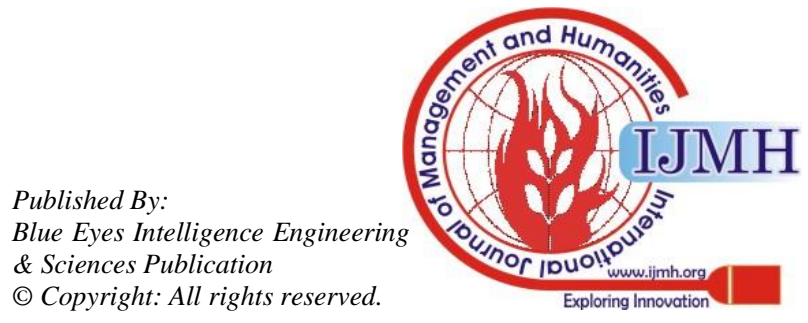


These techniques encourage students who are shy and do not participate in discussions with classmates. [36].

\section{TEACHER-CENTERED/STUDENT-CENTERE D LEARNING}

In the case of Malaysia, the ministry of education (MoE) developed a new curriculum known KSSR (Kurikulum Standard Sekolah Rendah) means primary school standard based curriculum which is based on student-centered learning and integrate language skills, approaches, standards, values and principles to teaching English for pupils [37, p. 198]. suggested that "In KSSR English pupils become more appreciative of their own efforts and will memorize things that they have worked on better". Similarly, [37] asserts that Malaysian students learn English language in an interactive way such as interaction between student and teacher, student and student, student and peer.

On the other hand, in Afghanistan, to most extent English language is taught through teacher centered methods, particularly in the case of primary schools. In other words, the teachers are the dominant figures in the classroom while pupils remain as a passive learner during the English sessions. [2] reveals that in Afghanistan, at all educational institutions, English language teaching practice is conducted based on grammar and Audio-lingual methods with teacher-centeredness. Therefore, practicing such approaches makes it difficult for Afghan learners to improve in effective communication skills.

Equally to Afghanistan and differently to Malaysia, in Saudi Arabia, teachers use traditional methods, namely teacher-centered method. [34] stated that in Saudi Arabia's public schools, English is not taught as means of communication. Instead it is taught as a subject that makes the lessons teacher-centered. [38] remarks that teaching and learning of EFL in Saudi classrooms is largely dominated by the teachers. Thus, English teaching is based on teacher-centered learning, and there is little opportunity for students to participate actively. Moreover, there is defect for a long time at the school level in the Saudi context; that is the English language curricula is not changing, and the traditional teacher-centered teaching as well as passive learning are used [39].

\section{TEACHING AIDS AND INSTRUCTIONAL MATERIALS}

In terms of quality and quantity in instructional materials for teaching English as an EFL/ESL, this varies from country to country. In Afghanistan, both in primary and secondary schools, English language instructors use only the textbooks that are supplied by the ministry of education. However, there does not include any supplementary materials which assist pupils in learning the language effectively. [40] states that Afghan primary and secondary school pupils are required to learn by rote the content of their English textbook and recall when they are asked. Another account for this issue is provided by [41] who stated that primary school level is divided into two parts; primary level and secondary level therefore, the year 4 is the first grade of secondary level of primary school, where pupils are called for to read the dense texts provided in the textbook and understand it. On the other hand, in the Malaysian context, English language teachers not only use the textbook provided by the ministry of education, but also they use journals, work sheets, cassette tapes, videotapes, Computer Assisted Language Learning (CALL) programs and games, radio cassette recorder sets and video recorders are placed and managed systematically [42]. Even though, some teachers still use textbook as a crucial material in Malaysian schools, more teachers which have had the training and skills adapt instructional materials based on learners' cognitive improvement, utilizing diverse reading activities to make the language easier to learn [42], [4].

In contrast to Malaysia, in the Saudi context, English language teachers only use textbooks distributed by the ministry of education. [43] stated that the factor which affects negatively the process of teaching and learning English in Saudi Arabia is the selection of inadequate and inappropriate teaching resources. In addition, important teaching resources are not provided in schools as well as there is unavailability of language computer laboratory. Furthermore, the lack of adequate teaching resources results in (a) Saudi English teachers not taking into account the use of teaching aids in the classroom; (b) teachers only depends on textbooks and blackboards during the teaching; (c) teachers often read to their students listening segment in the lesson; (d) some teachers design their own aid materials which are less effective [38].

\section{MAJOR CHALLENGES IN ELT PRACTICE}

Language teachers and learners around the world experience various challenges, problems and issues when busy with teaching and learning a language program particularly. In other words, teaching English language at primary, secondary and tertiary level challenges both language educators and pupils to face off until overcome the issue. In the case of Afghanistan, lack of time, proficiency in English, lack of computer skills, lack of a suitable teaching method and lack of teaching materials are the dominant challenges recorded by numerous researches [12], [44], [26], [9]. For Malaysian primary school teachers, the aforementioned challenges are not their concerns as their schools on the whole in urban centers have been supported by the government so that students have access to numerous resources. One of the major challenges however, for Malaysian school teachers is the lack of knowledge and training in the use of the new curriculum locally know KSSR (Kurrikulum Standard Sekolah Rendah) which requires English language teachers to be well accustomed with its content, objectives and implementation [3]. [3] argued that ministry of education needs to facilitate more trainings through which English language teachers could enhance their knowledge regarding the implementation of KSSR.

Many researches have mentioned the challenges faced by Saudi EFL learners and teachers. According to [45], like other non-English speaking learners, Saudi learners also face many challenges in learning English language. English is introduced at a late stage where students now more about discrimination, and what to choose, like or dislike. Another problem is that teachers are not proficient in English language.

Published By:

Blue Eyes Intelligence Engineering \& Sciences Publication

(C) Copyright: All rights reserved.

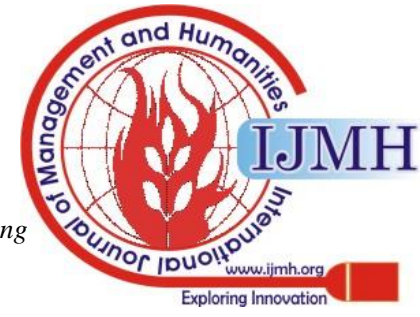


[45] additionally adds that curriculum is not up-to-date and teacher do not use information and communication technology (ICT) for their English language teaching as well as electronic devices are not used by the teachers to facilitate learning and teaching processes for the students. In addition, translation through first language (L1) is another problem, as L1 is used in the teaching of English rather than direct teaching approach. Also, the class atmosphere can be intimidating and discourages student participation. Furthermore, [46] add that there is insufficient development programs and in-service training. Another challenge is the weakness of in-service training program, low motivation for students, use of traditional teaching methods, unavailability of teaching aids and modern technology, weakness of school supplies and no existence of language laboratory are the major obstacles to teaching English in public education schools in Saudi Arabia

\section{CONCLUSION}

To conclude, this paper set out to discuss the similarities and differences of English Language Teaching Practice (ELTB) of Afghanistan, Malaysia and Saudi Arabia. The paper focused on some common aspects namely status of English Language as ESL or EFL, policy, religious and cultural perspectives, teaching and learning methods and materials. The discussion revealed some important differences and similarities of English language teaching practice at primary school level in some of the Asian countries: Afghanistan, Malaysia and Saudi Arabia. English language teaching at primary school level is practiced quite similarly in terms of aforementioned sub-topics in Afghanistan and Saudi Arabia while in the Malaysian context, there are some notable differences and improvements that exists. It is recommended that further empirical research is required to identify how these similarities and differences impacts both educators and pupils in learning English.

\section{REFERENCES}

1. Schmitz JR. Looking under Kachru's $(1982,1985)$ three circles model of World Englishes: the hidden reality and current challenges. Revista brasileira de linguística aplicada. 2014 Jun;14(2):373-411.

2. Alim, Z. Teaching English as a Foreign Language in Afghanistan. Parwan University. 2015 (1) Spring:1-12.

3. Sulaiman T, Ayub AF, Sulaiman S. curriculum change in English language curriculum advocates higher order thinking skills and standards-based assessments in Malaysian primary schools. Mediterranean Journal of Social Sciences. 2015 Mar 7;6(2):494.

4. Othman J. Teachers' instructional practices in teaching English at Malaysian primary schools.

5. Aljohani O. Does Teaching English in Saudi Primary Schools Affect Students' Academic Achievement in Arabic Subjects?. Advances in Language and Literary Studies. 2016 Feb 1;7(1):214-25.

6. Wedell M, Alshumaimeri Y. Putting out the fires: Supervisors' experiences of introducing primary English in Saudi Arabia. System. 2014 Oct 1; 46:120-30.

7. Chang BM. The Roles of English Language Education in Asian Context. Journal of Pan-Pacific Association of Applied Linguistics. 2011;15(1):191-206.

8. Choi YH, Lee HW. Current trends and issues in English language education in Asia. The Journal of AsiaTEFL. 2008;5(2):1-34.

9. Alamyar MN. Emerging Roles of English in Afghanistan. INTESOL Journal. 2017 Nov 15;14(1).

10. Mahboob A, Elyas T. English in the kingdom of Saudi Arabia. World Englishes. 2014 Mar;33(1):128-42. Cheragh-e-Hekmat Quarterly Academic and Research Journal of

11. Al-Ghamdi A, Al-Saadat E. The development of the educational system in Saudi Arabia. Riyadh, Saudi Arabia: Trabiat Al Ghad. 2002.

12. Sherani KS. Public and Private Schools in Afghanistan: Comparing some aspects of public and private schools in Kabul city. (2014).

13. Selvaraj B. English language teaching (ELT) curriculum reforms in Malaysia. Voice of Academia. 2010;5(1):51-60.

14. Al-Seghayer KS. The actuality, inefficiency, and needs of EFL teacher-preparation programs in Saudi Arabia. International Journal of Applied Linguistics and English Literature. 2014 Jan 1;3(1):143-51.

15. Jalaluddin NH, Norsimah MA, Kesumawati AB. The mastery of English language among lower secondary school students in Malaysia: A linguistic analysis. European Journal of Social Sciences. 2008 Nov;7(2):106-19.

16. Cannon G. English and other languages in Afghanistan. The Modern Language Journal. 1963 Nov;47(7):314-8.

17. Alshahrani M. A brief historical perspective of English in Saudi Arabia. Journal of Literature, Languages and Linguistics. 2016; 26:43-7.

18. Faruk SM. English Language Teaching in Saudi Arabia-A World System Perspective. Buletinul Stiintific al Universitatii Politehnica din Timisoara, Seria Limbi Moderne. 2013(12):73-80.

19. Wedell M, Alshumaimeri Y. Putting out the fires: Supervisors' experiences of introducing primary English in Saudi Arabia. System. 2014 Oct 1 ; 46:120-30.

20. Coleman H. The condition of English in multilingual Afghanistan.

21. Yamat H, Fisher R, Rich S. Revisiting English language learning among Malaysian children. Asian Social Science. 2014 Feb 1;10(3):174.

22. Ali NL, Hamid MO, Moni K. English in primary education in Malaysia: Policies, outcomes and stakeholders' lived experiences. Current Issues in Language Planning. 2011 May 1;12(2):147-66.

23. Alotaibi GN. Teaching English as a Foreign Language in the Early Grades of the Saudi Public Elementary Schools: Considering the Proposal. (2014).

24. Al-Seghayer KS. The actuality, inefficiency, and needs of EFL teacher-preparation programs in Saudi Arabia. International Journal of Applied Linguistics and English Literature. 2014 Jan 1;3(1):143-51.

25. Cheng KK, Beigi AB. Education and religion in Iran: The inclusiveness of EFL (English as a Foreign Language) textbooks. International Journal of Educational Development. 2012 Mar 1;32(2):310-5

26. Faiq, M. Teaching English in Afghanistan: (2006). available from https://www.usingenglish.com/articles/teaching-english-in-afghanistan. html

27. Ahmad IS, Abdullah H, Ghani A, Faizal M. Attitudes and motivation toward learning the English language among students from Islamic education system background: Exploring the views of teachers. Journal of Education and learning. 2014 Aug 1;8(3):195-208.

28. Mihat W. The English Language Curriculum in Malaysian Indigenous Primary Classrooms: The Reality and the Ideal. 3L: Language, Linguistics, Literature ${ }^{\circledR}$. 2015 Sep 22;21(3).

29. Ali NL, Hamid MO, Moni K. English in primary education in Malaysia: Policies, outcomes and stakeholders' lived experiences. Current Issues in Language Planning. 2011 May 1;12(2):147-66.

30. ur Rahman MM, Alhaisoni E. Teaching English in Saudi Arabia: prospects and challenges. Academic Research International. 2013 Jan 1;4(1):112.

31. Takal, G. M., \& Ibrahim, N. M. B. Afghan EFL Lecturers' Perceptions and Challenges in Communicative Language Teaching Implementation in Public Universities.

32. Hikmat A. The Effects of English Teaching Methods Course of the English Department of Kabul Education University on Secondary School English Teachers.

33. Sulaiman S, Sulaiman T, Rahim SS. Teachers' Perceptions of the Standard-Based English Language Curriculum in Malaysian Primary Schools. International Journal of Instruction. 2017 Jul;10(3):195-208.

34. Alharbi HA. Improving Students' English Speaking Proficiency in Saudi Public Schools. International Journal of Instruction. 2015 Jan;8(1):105-16.

35. Al-Seghayer K. Salient Key Features of Actual English Instructional Practices in Saudi Arabia. English Language Teaching. 2015;8(6):89-99.

36. Brown HD. Teaching by Principles, An Interactive Approach to Language Pedagogy. (2007). White Plains, NY: Pearson Education. 2008.

37. Azman H. Implementation and challenges of English language education reform in Malaysian primary schools. 3L: Language, Linguistics, Literature ${ }^{\circledR}$. 2016 Nov 25;22(3). 
English Language Teaching Practice (ELTP) at Primary School and Secondary Levels in some Asian Countries: A Comparison of Afghanistan, Malaysia and Saudi Arabia

38. Al-Seghayer K. The four most common constraints affecting English teaching in Saudi Arabia. International Journal of English Linguistics. 2014 Oct 1;4(5):17.

39. AlHarbi MS. Exploring English language teaching approaches in Saudi Higher Education in the West Province (Doctoral dissertation, University of Glasgow).

40. Modaser M. Teachers' Questioning and Feedback in Afghan otClassrooms: A study of grade 4 to 6 of primary school teachers in Kabul city. 2015.

41. Mahbobi M. Comparing teaching of Islamic and Language subjects in Afghanistan: Teachers' views and use of strategies in grade 4 of schools in Ghor Province.

42. Pandian A. English language teaching in Malaysia today. Asia Pacific Journal of Education. 2002 Jan 1;22(2):35-52

43. Fareh S. Challenges of teaching English in the Arab world: Why can't EFL programs deliver as expected? Procedia-Social and Behavioral Sciences. 2010 Jan 1;2(2):3600-4.

44. AHMAD A. ROLE OF ENGLISH IN AFGHAN LANGUAGE POLICY PLANNING WITH ITS IMPACT ON NATIONAL INTEGRATION (2001-2010) (Doctoral dissertation, UNIVERSITY OF PESHAWAR PAKISTAN).

45. Al-Nasser AS. Problems of English language acquisition in Saudi Arabia: An exploratory-cum-remedial study. Theory and Practice in Language Studies. 2015 Aug 11;5(8):1612-9.

46. Elyas T, Al Grigri WH. Obstacles to teaching English in Saudi Arabia public schools: Teachers' and supervisors' perceptions. International Journal of English Language Teaching. 2014;2(3):74-89.

\section{AUTHORS PROFILE}

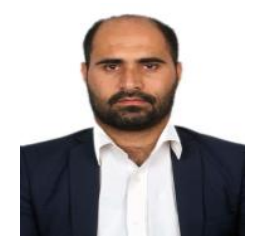

Mohammad Sharif Hasanzoy, is currently a master student in TESL program at University Technology Malaysia. After graduation at bachelor level from Kabul University in 2010, he joined as an academic member in education faculty at Kunduz University where he has been teaching English as Foreign Language since 2011. Besides, he was assigned as a head of English department from 2016 to 2017 when he was in charge of both teaching and academic affairs. Mohammad Sharif Hasaznoy's first paper entitled (Writing Anxiety and overcoming strategies among Afghan tertiary students) was published in April/2019.

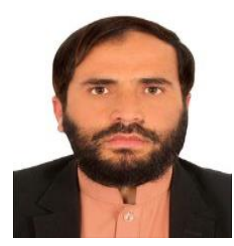

Saifurrahman Rahmani, was born in 1985/June/10 in Paktia province of Afghanistan. He studied primary and High School in Haripur, Pakistan. After graduation from the high school, he took the Kankur (university entrance exam) and passed to the Faculty of Languages and Literature of Nangarhar University, Afghanistan. He graduated from English Language and Literature Faculty. He is one of the academic member of Sheikh Zayed University, Khost, Afghanistan. He worked as assistant of the Language and Literature Faculty in 2017. Currently, he is a Master level student of TESL at University Teknology Malaysia (UTM).

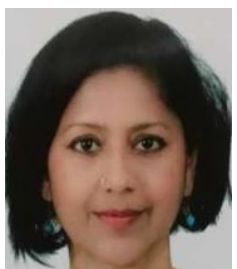

Sandaran, SC. (Ph.D), senior lecturer. Areas of interest: Critical Discourse Analysis, TESL, Service Learning, Engineering Texts. Language Academy, Faculty of Social Sciences and Humanities, Universiti Teknologi Malaysia. Tel: +60167771364 E-mail: shanti@utm.my 